\title{
The Effect of Job Satisfaction and Organizational Commitment On Work Engagement and Performance
}

\author{
Andi Caesar To Tadampali \\ Universitas Negeri Makassar \\ Makassar, Indonesia
}

\author{
Abdul Hadi \\ Universitas Negeri Makassar \\ Makassar, Indonesia
}

\begin{abstract}
This study aims to determine the effect of job satisfaction and job involvement directly on the performance and indirectly through organizational commitment as an intervening variable. The results showed that job satisfaction variables gave significant positive effect directly on employee performance. Moreover, another variable such as work engagement also contributed significant positive effect on employee performance directly. Through the mediation of organizational commitment, job satisfaction and job involvement gave significant positive effect indirectly on employee performance.
\end{abstract}

Keywords-organizational culture; leadership styles; organizational commitment.

\section{INTRODUCTION}

Human resource is one of the resources that determine the success of the organization. Therefore, organizations are required to manage human resources for their survival. Chungtai stated that the company that can improve the morale and enthusiasm of its employees would get the most benefit [1].

Employee engagement is one issue in management reviews. This variable is useful in improving company productivity. Moreover, Chandrasekar emphasized that there were many aspects related to the work such as interaction with co-workers, managers, following the rules and particular work environment which is sometimes not sufficient or less preferred [2]. The phenomenon that often arises today is a lack of the achievement of the effectiveness of the company caused by the high turnover rate and absenteeism of employees in the workplace. They indicate low levels of organizational commitment that is owned by the employees.

Employees with high organizational commitment have a different attitude than those who have low commitment. The significant organizational commitment will produce high work performance, low absenteeism, and low levels of employee turnover. Employees who are committed will have high productivity [3]. Organizational commitment can encourage employees to keep their jobs and show the expected results. On the other hand, low employee commitment will bring negative impact to the company [4].

Another factor that should be concerned in improving the performance of employees is the job satisfaction of the employees. It is because employees who do not feel comfortable and less respected in their work cannot develop all the potential they have. Automatically, the employee will be unable to focus and concentrate fully on his work. Theoretically, Aziri suggested that there are three reasons for the importance of job satisfaction in the organization. First, employees who are not satisfied will not care about the job and might resign. Secondly, satisfied employees will have better health and longer life. Third, job satisfaction will be brought to life outside of work [5]. Several research studies also show job satisfaction and organizational commitment. Mathis and Jackson mentioned that people are relatively satisfied with their jobs will be more committed to the organization [6], Furthermore, Huang and Hsiao also claimed that there was a significant and positive relationship between job satisfaction and organizational commitment [7]. Employees will have a strong commitment when they felt satisfied with the work, supervision, salary, promotion, and coworkers [8].

Employees who have a high level of job involvement will be sided with the company, and care about their fieldwork performance. Employees who involved in the work tend to be more motivated to work well [1]. Employee involvement or participation in the important work has to be taking care by companies as the work engagement will cause the employee's willingness and happiness to cooperate with each other, either with superiors or with colleagues [9]. The performance of a company or organization is an accumulation of all individuals' performance who work in it. In other words, efforts to improve the company's performance were made by improving the performance of each. Finding out the effect of job satisfaction and job involvement directly on the performance and indirectly through organizational commitment as an intervening variable in BTN Bank Branch Office in Makassar comprises the objective of this research.

\section{METHOD}

The research was conducted on BTN Bank Branch Office Makassar. This study is the explanation (critical research). The employees of Bank BTN Makassar Branch Office who were in total 360 people is the population of this research. The sample was taken by using judgmental sampling technique which is divided into two divisions, business division, and the supporting division. The sample was the core employees and 
placed on the BTN Bank Branch Office Makassar amounted to 119 employees.

Validity test is done by comparing the value count with the table. If count $<1_{\text {abel }}$ and has positive value then the items or statements or indicators are declared to be valid. Test reliability was calculated using Cronbach Alpha> 0.60 which shows the instrument used is reliable.

$$
\begin{gathered}
\mathrm{Y}_{1}=\mathrm{a}+\beta_{1} \mathrm{X}_{1}+\beta_{1} \mathrm{X}_{2}+\mathrm{e}_{1} \\
\mathrm{Y}_{2}=\mathrm{a}+\beta_{1} \mathrm{X}_{1}+\beta_{1} \mathrm{X}_{2}+\beta_{2} \mathrm{Y}_{1}+\mathrm{e}_{1}
\end{gathered}
$$

Remark :

$\mathrm{X} 1$ : Job Satisfaction

$\mathrm{X} 2$ : Work Engagement

$\mathrm{Y} 1$ : Organizational Commitment

Y2 : Employee Performance

B : Regression Coefficients

E : error

\section{RESULTS}

The amount of the adjusted R-square for the substructure equation 1 is 0.128 or $12.8 \%$ where variable job satisfaction and job involvement were able to explain the variable of organizational commitment by $12.8 \%$ and the remaining $87.2 \%$ is explained by other variables outside the model that are not included in this analysis.

The amount of the adjusted R-square for the substructure equation 2 is 0.631 , or by $63.1 \%$ where variable job satisfaction and job involvement through organizational commitment can explain the variable performance of $63.1 \%$ and the remaining $36.9 \%$ is explained by other variables outside the model which are not included in this analysis.

Statistical test results showed that the equation $F$ substructure 1 has a significance value of 0.001 (smaller than an alpha value of 0.05). This indicated that there are significant job satisfaction and job involvement on organizational commitment. Statistical test results showed that the equation $\mathrm{F}$ substructure 2 has a significance value of 0.000 <of the alpha value of 0.05 . This demonstrated that there are significant job satisfaction and job involvement through an organizational commitment to performance.

Based on the result obtained from data processing for this study model, then the model diagram depicted in Figure 1 with the following equation.

Substructure 1equation:

$\mathrm{Y} 1=0,473 \mathrm{X} 1+0,197 \mathrm{X} 2+0,923$

Substructure 2 equation:

$$
\begin{aligned}
& \mathrm{Y} 2=-0,354 \mathrm{X} 1+0,364 \mathrm{X} 2+0,344 \mathrm{Y} 1+0,597 \\
& \mathrm{E} 1, \mathrm{E} 2 \quad: \text { Error }=\sqrt{1-\mathrm{R}^{2}}
\end{aligned}
$$

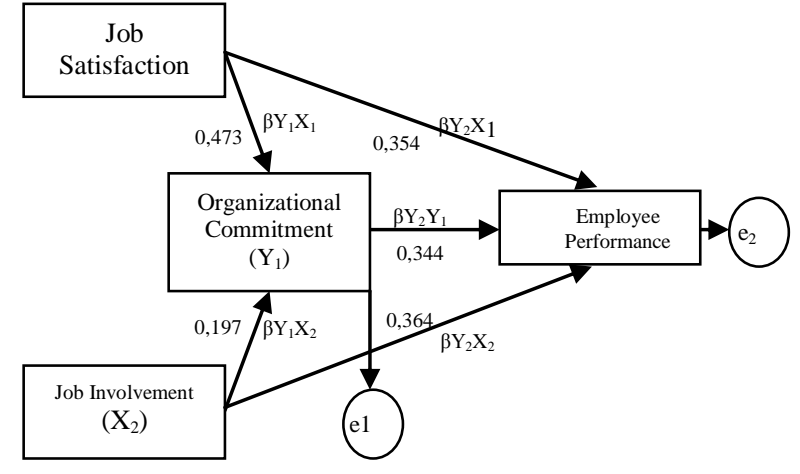

Fig. 1. Diagram of Path Analysis

The influence of job satisfaction on the performance has a value standardized beta coefficient of 0.354 and the probability of the significant value of $0.000(<0.05)$. It means that there is a positive and meaningful relationship between job satisfaction and work performance. Work engagement influence on the performance has a value standardized beta coefficient of 0.364 and the probability of the significant value of $0.000(<0.05)$ which means that there is a positive and meaningful relationship between job involvement on work performance. The influence of organizational commitment to performance value standardized beta coefficients of 0.344 , and the probability of the significant value of $0.000(<0.05)$ means that there is a positive and significant relationship between organizational commitment to performance.

Based on the calculation of direct influence, the influence of job satisfaction on the performance had a positive correlation of 0.354 . Thus, the $\mathrm{H} 1$ hypothesis which states that the Organizational Climate has a significant effect on job satisfaction is accepted. Influence on the performance of work engagement had a positive correlation of 0.364 . Thus, H2 which states that the work involved has a direct and significant impact on performance is acceptable. The influence of organizational commitment to performance has a positive correlation of 0.344 . Thus $\mathrm{H} 3$ stating that organizational commitment has a direct and significant impact on performance is acceptable.

The significant influence of job satisfaction on organizational commitment and employee performance is based on experts. Job satisfaction is psychological responses about the job environment. The responses indicated of cognitive aspect, affective aspects and behavioral components [10]. Cognitive aspects include the ability of employees in utilizing information technology. For employees who have knowledge and skills about computer technology and intelligence will facilitate the completion of work. The effective aspect appears to be the loyalty of the individual to his work. Employees with real loyalty always strive to work professionally. With real loyalty, employee performance is also high.

A person's affective aspect is part of the motivation. Theoretically, motivation is born from within a person (internal motivation) and driven by external factors (external motivation). The desire to achieve and the needs that must be 
met encourage employee morale. The higher the desire and the need, the work motivation is also higher.

\section{CONCLUSION}

Job Satisfaction has a positive and significant effect on employee performance at BTN KC. Makassar directly. Job satisfaction also gave a positive influence on Organizational Commitment. Furthermore, Job Satisfaction gave significant positive effect on the Performance indirectly through Organizational Commitment. Work Engagement has a positive and meaningful effect on employee performance BTN KC. Makassar and it also has the greatest effect in improving performance directly. Work Engagement positively influenced on Organizational Commitment.

\section{References}

[1] A. A. Chughtai, "Impact of job involvement on in-role job performance and organizational citizenship behaviour," J. Behav. Appl. Manag., vol. 9, no. 2, p. 169, 2008.

[2] K. Chandrasekar, "Workplace environment and its impact on organisational performance in public sector organisations," Int. J. Enterp. Comput. Bus. Syst., vol. 1, no. 1, pp. 1-16, 2011.

[3] F. Luthans, "Organizational Behaviour, 9. bs." New York: McGraw-Hill Companies Inc, 2002.

[4] H. M. P. Tooksoon, "Conceptual framework on the relationship between human resource management practices, job satisfaction, and turnover," J. Econ. Behav. Stud., vol. 2, pp. 41-49, 2011.

[5] B. Aziri, "Job satisfaction: A literature review," Manag. Res. Pract., vol. 3, no. 4, pp. 77-86, 2011.

[6] R. L. Mathis and J. H. Jackson, Human resource management: Essential perspectives. Cengage Learning, 2011.

[7] T.-C. Huang and W.-J. Hsiao, "The causal relationship between job satisfaction and organizational commitment," Soc. Behav. Personal. an Int. J., vol. 35, no. 9, pp. 1265-1276, 2007.

[8] E. J. Lumley, M. Coetzee, R. Tladinyane, and N. Ferreira, "Exploring the job satisfaction and organisational commitment of employees in the information technology environment," South. African Bus. Rev., vol. 15, no. 1, pp. 100-118, 2011.

[9] Y. D. Billing, "7. Happily working until they drop: when there is no longer a balance between stress and fun-a task for leadership," Crit. Perspect. Leadersh. Emot. Toxicity, Dysfunct., p. 127, 2013.

[10] C. L. Hulin and T. A. Judge, "Job attitudes," Handb. Psychol., 2003. 